\title{
Corrected Prolonged QT Interval by ECG
} Finding

National Cancer Institute

\section{Source}

National Cancer Institute. Corrected Prolonged QT Interval by ECG Finding. NCI

Thesaurus. Code C83817.

An electrocardiographic finding in which the QT c interval corrected for heart rate is prolonged. Thresholds for different age, gender, and patient populations exist. (CDISC) 